\title{
Immigrant crime in Taiwan: perspectives from Eastern Asia
}

\begin{abstract}
The objective of this study is to test Hirschi's social bonding theory by exploring the relationship between immigration and crime in Taiwan. Taiwan is a developed country with a large immigrant population from East Asian countries and Mainland China. Social disorganization theory, strain and opportunity theories, and cultural theories have been developed to provide explanations for immigrant crime nearly hundred years ago. Tests of the above theories, however, find little support for hypotheses. Hirschi ${ }^{1}$ suggests that the more attached persons are to other members of the society, the more they believe in the values of conventional society, and the more they invest in and are involved in conventional lines of activity, the less likely they are to deviate. Four elements including attachment, commitment, involvement, and belief of social bonding theory were tested with immigrants in Taiwan. This study contains 256 responses from Taipei prison and 237 non-offender responses from Taiwan's five cities and counties. This study used logistic regression to predict immigrant crime and applied multiple regression to predict immigrant delinquency. There were several propositions tested in this study that may add to existing scholarship. First, this study, using Taiwan's sample, empirically studied social bonding theory and tested its validity across a different culture and country while the number of studies of social bonding theory conducted in East Asia is fairly small. Secondly, belief is the single best predictor of immigrant crime and delinquency rate. Age and gender have significant effects on predicting immigrant crime and delinquency. Third, immigrants who work full time and hold strong beliefs are less likely to engage in criminal and delinquent acts.
\end{abstract}

Keywords: Taiwan, social bonding theory, immigration crime, attachment, commitment, involvement, belief
Volume 6 Issue 3- 2018

\author{
Wen-Chih Billy Huang \\ Department of Criminal Justice, Central Police University, \\ Taiwan
}

Correspondence: Wen-Chih Billy Huang, Central Police University, No.56, Shujen Rd., Takang Vil., Kueishan District, Taoyuan City 33304, Taiwan, Tel +886-983। 20498, Email billyhuang@hotmail.com, huang.billyhuang@gmail.com, billyhuang@mail.cpu.edu.tw

Received: June 20, 20I8 | Published: June 25, 2018

\section{Introduction}

The popular perception in the US and in many European countries is that "foreigners," recent immigrants, or their descendants, are disproportionately involved in crime. Tanton \& Lutton ${ }^{2}$ indicate that public beliefs causally connected immigration with crime and they coincided with historically high rates of immigration through the first decades of the 20th century in the US. Politicians also frequently draw a causal relationship between immigration and crime. Public perceptions of immigrant public drunkenness in association with fears of crime facilitated the passage of restrictive immigration policies in American history. These sentiments have been premised on the assumption that immigrants engage in more criminal activity (e.g., violent or property crime) than non-immigrants. More generally, immigrants cause a host of other social problems, such as depleting welfare resources, increasing native-born unemployment and housing shortages, overwhelming school and health systems, and undermining the existing social order. ${ }^{3,4}$ Do some immigrant groups engage in higher rates of certain types of criminal behavior than other groups? And what's the etiological cause of certain types of immigrant crime? Such questions illustrate the importance of clarifying precisely what is meant by an immigration-crime nexus. Few criminologists have conducted comprehensive research that compares Asian Americans and non-Asian Americans in deviance and crime. ${ }^{5}$ Taiwan was chosen in this study because it represents a developed country which has huge immigrant population from East Asian countries. This study attempted to analyze the etiological cause of Taiwan's immigrant crime by applying social bonding theory. The research hypothesis is that the weakening or broken bonds between immigrant and their countries of origin are assumed to cause delinquent behavior and crime after they entered Taiwan. On the other hand, the strengths gained from the new bonds they establish in Taiwan was tested at the same time.

\section{Push and pull factors of Taiwan's immigration}

Taiwan has a developed capitalist economy that ranks as the 19th largest in the world by Purchasing Power Parity (PPP) and 24th in nominal GDP of investment and foreign trade. Traditional laborintensive industries are steadily being moved off-shore and replaced with more capital- and technology-intensive industries, as well as creative industries. ${ }^{6}$ Since 1986, there have been indications that Taiwan has been experiencing rapid increase in immigration. ${ }^{7}$ The "pull" and "push" factors originated from the "Migration Law" are used to explain the influx of immigration. Taiwan's economic development and the policies in the labor market act as major pull factors, then turn to push factors that attract legal and illegal immigration. Taiwan achieved substantial economic growth during the past five decades. However, Taiwan has undergone a series of economic restructuring which created labor shortages in certain sectors. In addition, expansion of secondary, trade/technical and tertiary education have resulted in sectoral shortages of labor. The supply of transferable labor (from agriculture to either industry or the service sector) has been depleted. The decline in fertility since 1952 means that fewer workers entered the labor force. Since 1990, the development of labor importation 
policies and programs has been very rapid. In the meanwhile, the number of foreign workers has increased significantly. Nevertheless, their wages were about 30 percent lower than Taiwanese wages: 36 percent lower in construction, and 27 percent lower in manufacturing. ${ }^{8}$ What motivates workers to leave their countries of origin? Three crude measures can be used to answer this question. They are

i. Growth of gross domestic products;

ii. Unemployment rates;

iii. Wages.

For all three measures, the sending countries are found to offer situations inferior to those found in Taiwan. Presumably, differentials in wages and unemployment are sufficient to attract legal or illegal immigration to Taiwan. ${ }^{9}$ In addition, all of the countries of origins are located close enough for relatively easy assess to Taiwan. ${ }^{9}$

\section{Demography of immigrants in Taiwan}

According to $\mathrm{Chen}^{10}$ there are three categories of legal immigration defined in Taiwan's "Employment Services Act," and "Immigration and Entry Act." First, white-collar immigrants are those holding foreign passports who stay in Taiwan for the purposes of professional, technician, and investment-oriented status. Examples are English teachers, college professors, sport athletes, priests, missionaries, or CEOs of cross-border companies. Secondly, blue-collar immigrants refer to those foreign contract workers whose entry was legally approved by the Taiwan government. For example, care-takers, house maids, fishermen, factory and construction workers. Third, foreign spouses of Taiwanese citizens, whose working condition are not required to be approved by Taiwan government. There were total of 447,030 foreigners legally registering in Taiwan in 2011 which does not include Chinese immigrants. Almost 80 percentage (79.42 percent or 355,071 people) were blue-collar contract workers. 15,449 (3.45 percent) were doing white-collar jobs. In 2011, 53,808 foreigners who were holders of foreign residency certificates (FRC) or permanent residency certificates (PRC) in Taiwan. Foreigners who are granted residence visa are required to apply to the FRC within 15 days after their entry. The required conditions for applying to the PRC are as follows: foreign nationals who have legally and continuously resided in Taiwan for five years and have stayed for more than half a year in each year, or the alien spouse and/or children of a Taiwan national with valid household registration in the Taiwan area who have legally resided for 10 years, during which period the spouse and/or children have physically resided for more than half year in each year for at least five years.

More than 90 percent of the foreign population is composed of nationals from South Eastern Asian countries. To be more specific, 34.11 percent foreigners (or 152,488 people) were from Indonesia, followed by Vietnam (93,519 people or 20.92 percent), the Philippines (78,090 people or 17.46 percent), Thailand (74,073 people or 16.57 percent), and Malaysia (7,958 people or 1.78 percent). Female foreign workers from Indonesia and the Philippines outnumber male workers. On the contrary, there are as many as four times male workers than female workers from Thailand. The number of Vietnam's male workers is slightly higher than that of female workers. In Tsai and Tsay's survey (1991), they found that foreign workers, especially the illegal ones, fill vacancies at the lower end of the labor market. Most of the foreigners take the dirty, dangerous, and difficult jobs in manufacturing, construction, and household service industries, which were unwanted by local workers. ${ }^{8}$ Unlike the legally imported contract workers, the illegal workers show a rather high rate of job turnover. This tendency is related to their illegal status as well as the possible exploitation by and conflicts with, the employers and the job brokers.

Besides the immigrants who hold foreign passport, people who migrated from Mainland China, Hong Kong and Macao and reside in Taiwan are also regarded as immigrants in this study. Although their entry and staying are not regulated by Taiwan's Immigration Act, the "China -Taiwan People Exchange Code" poses parallel regulations as strict as foreign immigrants. Between 1991 and August 2011, there were 286,669 individuals, from China, Hong Kong, and Macao, who were granted residence admission by the Taiwan government. In addition, 155,711 people in total received residence certificates, which mean they were qualified to permanently stay in Taiwan. Due to the unique political circumstances between the People's Republic of China (PRC) and Taiwan (ROC), Chinese immigrants migrating into Taiwan are defined as a special category, which is not included in the "Immigration Act" as foreign nationals. Rather, their entry and staying are regulated by the Act of "China-Taiwan People Exchange Code." This research regards Chinese people as foreign immigrants, whether they stay Taiwan legally or illegally.

\section{Crimes and arrests of immigrants: official statistics}

National Immigration Agency estimated that, as of August 2011, 106,951 illegal foreign workers had been deported, and 31,170 illegal foreign workers remained in Taiwan. Vietnamese and Indonesian are two of the biggest groups that took up 90 percent of illegal immigrant populations. There has also been a steady increase in illegal immigration from China between 1987 and 1993. After 1993, the annual average was around 1,500 illegal Chinese immigrants; the figure jumped to 3,000-plus in year 2003. At the same time, the ratio of female immigrants has risen to more than 70 percent of the total. This reveals that illegal immigration problem is no longer just a case of simple laborers coming to Taiwan, but has already developed into a serious problem with organized criminal gangs manipulating events from behind the scenes. ${ }^{11}$ In regard to the characteristics of potential illegal immigrants, the most likely persons to attempt illegal migration are young single males, who prefer blue-collar or agricultural work. ${ }^{12}$ A person is also more likely to migrate illegally if friends or relatives have previously succeeded. ${ }^{13}$ Most illegal migrants move short distances and to where international communications are cheap. ${ }^{9}$ Followed by the increased illegal immigration, the number of foreign inmates in Taiwan has also skyrocketed from 198 in the year 2002 to 1986 in 2008, marking a 10 times increase within 7 years. ${ }^{14-20}$ Further analyzing the foreign prisoners by their nationalities, Chinese took up 34.1 percent (677 prisoners) followed by 469 Vietnamese (23.6 percent), 257 Thai (12.9 percent), and 224 Indonesian (11.3 percent). The inmates from China, Vietnam, Thailand, and Indonesia compose 80 percent of the whole population.

Among 677 Chinese prisoners, 174 were convicted of document fraud (25.7 percent), 172 were smuggled into Taiwan which violated Taiwan's National Security Law (25.4), and 102 were against Entrance and Immigration Act (15.1 percent). As mentioned, 469 Vietnamese were the second largest group in prison. Of these 173 of them committed document fraud (36.9 percent), 139 committed theft $(29.6$ percent) and 59 violated the Entrance and Immigration Act (12.6 percent). A high percentage of Thai and Indonesian inmates committed document fraud and theft. It is noteworthy that 91 from 111 Malaysian inmates were drug offenders who were convicted of selling, shipping, and manufacturing the drugs. ${ }^{21,22}$ According to the 
statistics of Taiwan's National Immigration Agency, 33,564 Chinese immigrants violated Taiwan's laws between 1992 and 2011. The crimes are focusing on document fraud and the breach of National Security Laws and China -Taiwan People Exchange Code. Their sentences were 6 years in average which indicates high proportion in felonies such as smuggling, drug-trafficking, violation of public security, fraudulent, forced sex, fraud and gambling. Among them, almost 10,000 were working in Taiwan without legal permits.

\section{Literature review}

The nexus between crime and immigration has been studied and hotly debated over a century in the United States. ${ }^{23}$ Social disorganization theory first suggested that new immigrants typically move to urban neighborhoods characterized by poverty, substandard housing, poor school, and high crime rates ${ }^{11,24-26}$ In such highly disorganized areas, residents with high rates of mobility do not develop a sense of shared values and thus become more likely to engage in crime. When immigrants face cultural and social barriers in their attempts to assimilate into U.S. society and find few prospects to achieve social goals legitimately, social strain and opportunity theories suggest that immigrants may turn to illegitimate means, such as crimes, to overcome blocked economic opportunities or to organized crime to gain a foothold in politics. ${ }^{27}$ Following this line, cultural theories suggest that certain immigrant groups develop criminal behavior as adaptations to adverse conditions and such behavior eventually becomes normative. ${ }^{28}$ However, tests of above theories find little support for hypotheses about immigrant crime, or the findings at best are mixed. Empirical tests of these different theories fail to assess adequately the role of key variables, such as "social disorganization," "strain," "cultural values," and they generally rely on unreliable and inaccurate data sources. ${ }^{23,28}$ At the same time, some contemporary U.S studies have suggested a more paradoxical finding: Immigrants are less likely to engage in crime. This conclusion also emerges from the 1901 Industrial Commission, the 1911 Immigration Commission, the 1931 Wickersham Report, and the 1994 U.S. Commission on Immigration Reform. ${ }^{23,28}$ Most empirical research suggests many immigrant groups consistently demonstrate significantly lower crime rates than do native populations. ${ }^{3}$ Hagan $\&$ his colleagues ${ }^{29}$ found generational status to be the most significant predictor of youth delinquency when they used scores from a delinquency and drug use scale of two cohorts near Toronto. ${ }^{29,30}$ Cross-national studies suggest that cultural as well as structural factors should be considered as an explanation of racial/ ethnicity difference, given the substantially different crime pattern between structurally similarly situated immigrants. ${ }^{5,31}$ For example, Asian American adolescents commit less deviance in the form of school misbehavior than white, black, Hispanic, or Native American adolescents. $^{5}$

Sung's study applied social control and social learning theories to the observed differences and explained race/ethnic difference by family backgrounds and school bonding. Batta et al., ${ }^{32}$ attribute lower crime rates among Asian immigrants in England to their effective social control through strong family units based within a wider kinship network, family stability, and traditional moral values supported by shared religious belief. ${ }^{5}$ It is sometimes stated that the greater the cultural distance between an immigration group and a host country, the more difficult will be the group's integration into the new society and the greater the risks for maladjustment and criminal activities. ${ }^{5}$ In these instances, in which immigration is rather limited, there may be unique social networks and selection processes that explain the higher rates or lower rates of crime involvement. If legal immigration from these countries were allowed to increase, it is plausible that rates of crime associated with these immigrant groups in the United States would substantially decline, if only because the effects of these selection processes and social networks would be diluted. There also are notable complexities that existing theories are unable to address. For example, some immigrant group have higher crime and imprisonment rates than non-immigrants, while others have considerably lower rates, even when age and gender compositional differences are taken into account; ;31,33,34 different immigrant groups in similar socioeconomic structural contexts frequently evidence different crime patterns; ${ }^{: 31,34}$ and, although cities with high immigration rates tend to have higher crime rates, there appears to be little or no relationship between changes in immigration and changes in crime, whether controlling for compositional factors such as age and gender or not. . $^{3,34}$ Therefore, contemporary crimes and immigration theories indicate the need for disaggregating crime rates along certain dimensions (e.g. age and gender, foreign-born vs. Taiwan-born, country of origin, motivation for immigration) as well as data collection based on various potential criminogenic factors (e.g., peer associations, family structure, community socioeconomic context) for specific immigrant groups.

\section{Empirical studies from East Asia}

The number of studies of social bonding theory conducted in East Asia is fairly small, including three in China by Cretacci et al., ${ }^{35,36}, \mathrm{Lu}$ et al., ${ }^{37}$ two in Hong Kong by Cheung \& Cheung ${ }^{38}$, Chui \& Chan $^{39}$, and one in Korea by Hwang \& Akers ${ }^{40}$. Hwang \& Akers ${ }^{40}$ reported their findings from a self-report questionnaire survey of a sample of 1,035 high school students in Pusan, Korea. They found the influence of parental variables was generally less than the influence of the peer variables for all types of drug behaviors among these adolescents. Rather than explained by social bonding theory, they suggested their findings were more conformed to the expectations of social learning theory, even though the stability and authority of the family is greater in South Korean society. Cretacci el al..$^{35,36}$ collected data in a large Chinese University located in Beijing in the fall of 2007. In their first study published in 2009, Cretacci el al., ${ }^{35}$ tested both Grasmick et al., ${ }^{41}$ traditional scale and Hirschi's ${ }^{42}$ revised measure of self-control. Hirschi (2004) revised the conceptualization of low self-control to reflect a one-dimensional, social bond type measure. ${ }^{43}$ They found Chinese deviance may be better predicted on deteriorating social bonds and the revised measure is an important indicator in modeling crime in Chinese society. ${ }^{43}$ Following their pointing that future research should focus on what types of items make up the best measure of the revised self-control scale and test those measures ${ }^{35,36}$ used the same data set and formulated three separate factors (maternal relationship, school attachment, and school authority) in their later study. They found revised the bond measure was a strong correlation of deviance, although only school correlation was significant. This finding is also consistent with Bouffard \& Rice' ${ }^{44}$ results that they tested Hirschi's redefinition of self-control by asking respondents to identify perceived costs and salience as a measure of self-control. They found the social bond impacts offending likelihood, fewer bonds exhibit less self-control by considering fewer costs and less salient when making a decision (p. 138). Similarly, Cheung \& Cheung ${ }^{38}$ measured social bonds and peer influence in a sample of 1,015 adolescents in Hong Kong. They failed to find evidence that self-control had an impact on delinquency, but found low self-control was linked to a range of negative social conditions in Chinese adolescents, including disrupted 
social bonds, coercive parenting, negative relations with peers, etc. In their recent study, $\mathrm{Lu}$ et al., ${ }^{37}$ tested the role of social bonds and examined the power of self-control theory as an explanation of juvenile minor risky and delinquent behaviors in China.

They used measurements of attachment (family, school, and neighborhood), commitment (to school), involvement (in conventional activities), and belief (support of pro-violent values) to test the social bonding theory, but claimed the operationalization of four concepts was less than optimal for the Chinese context (p. 15). Among the social bonding factors, beliefs (pro-violence attitude) and family bonding were found to be the significant predictors of risky behavior and minor delinquency. However, the effects of selfcontrol remain when controlling for social bonding measures. (p. 1). Claiming no study in the past has examined all Hirschi's social bond elements with Asian samples, Chui \& Chan ${ }^{39}$ tested this theory with a sample of 1,377 adolescents aged between 12 and 17 years who were randomly selected out of nine selected secondary schools in Hong Kong. They examined the differential social bond effects in predicting the propensity to commit theft and violent crime, with and without controlling their age and gender. Findings indicated that a strong belief in the legal system, a healthy parent-child bonding, and a strong school commitment are significant predictor to prevent adolescents from engaging theft and violent delinquency. However, the increased level of involvement in organizational activities is likely to result in the increase of propensity to involve in delinquent conducts (p. 371).

\section{Research methods}

Developing informed theoretical accounts of the immigrationcrime nexus is important because such accounts provide an opportunity to modify, expand, and ultimately improve criminological and immigration theory. ${ }^{3}$ In this study, Hirschi's social bonding theory was adopted as an attempt to expand immigration literature. Hirschi posits that "delinquent acts result when an individual's bond to society is weak or broken" 45 and "the more closely a person is tied to conventional society in any of these ways, the more closely he is likely to be tied in the other ways......who is attached to conventional people is, for example, more likely to be involved in conventional activities and to accept conventional notions of desirable conduct". ${ }^{45}$ Although he often uses the phrase "attachment to conventional others," Hirschi maintains that it really does not matter to whom one is attached. In Hirschi's theory, an adolescent's attachment to parents can be measured by close parental supervision and discipline, quality of communication and time spent together, affectional identification with parents, and parents' knowledge of children's peers. ${ }^{45-48}$ Adult childparent relationship is also seen as a stronger predictor of desistence among the subjects with poor romantic relationship bonds. ${ }^{49}$ In this study, being attached or bonded to a parent means that the immigrants are likely to be more supervised than the immigrants with weaker bonds. However, due to the lack of parents' presence after immigrants moved into host country, this sort of "direct control" explanation is hypothesized only partial at best. Hirschi also stresses that attachment to peers can control delinquency tendencies. The delinquent "peer effect" becomes strongest when the adolescent has strong attachment to delinquent peers and when peer behave delinquently. ${ }^{47}$ In this study, it is hypothesized if the immigrant, no matter legal or illegal, can develop attachment to other earlier-migrating immigrant, he or she certainly will foster the bonding and draw for the resources of financial help, information, housing and jobs. These resources of support may be especially reliable if the immigrants are also family members or close kin, because kinship forges bonds of expected reciprocity and mutual support. ${ }^{50}$ As Hirschi ${ }^{45}$ states, "control theory assumes that the bond of affection for conventional persons is a major deterrent to crime," however, little in criminological research indicates the role of employment in adulthood has been the dominant factors identified within criminal literature in promoting criminal desistence. ${ }^{49}$

Commitment refers to the extent to which individuals have built up an investment in conventionality or a "stake in conformity". ${ }^{47,51}$ Appling this idea to immigrants, investment in occupational endeavors builds up this commitment. The more stable and more earnings of a job, the greater the commitment is for the immigrants. Commitment is also measured by occupational aspirations and expectations.

Involvement refers to one's engrossment in conventional activities such as studying, spending time with the family, and participation in extra-curricular activities. Adolescent involvement in conventional activities includes working part-time, dating, playing sports, engaging recreation and hobbies, doing homework, and spending time with friends. However, Hirschi ${ }^{45}$ affirmed that delinquent act can take just minutes to commit, involvement in conventional activities alone is therefore insufficient to deter delinquency. Begg et al., ${ }^{52}$ found that involvement in organized sports, in fact, may increase the risk of delinquency involvement especially among male adolescent. ${ }^{39}$ Belief is commonly defined as the respect for moral validity of social norms and rules. Individuals who hold strong moral beliefs and conventional norms are less likely to engage in delinquency. Religion is also regarded as an important social factor which has significant effect to deter crime committing. The researcher, therefore, took account of religion effect and integrated it into belief's measurements in this study. Chriss $^{53}$ asserts the content of beliefs, i.e. moral element in the attachment, playing a crucial role in deterring a child from committing a deviant act when a parent is physically distance. This sort of "indirect control" is more important than attachments represented. A person who identifies himself or herself as a conventional person is the person who is more likely to consider long-term consequences of their actions and deeds. ${ }^{53}$ Hirschi \& Stark ${ }^{45}$ found that adherence to basic moral values and an acceptance of conventional authority are both strongly and negatively related to delinquency among high-school students. ${ }^{54}$ Belief is therefore defined as the endorsement of general conventional values and norms. Belief is measured by reference to values relative to the law and the criminal justice system. This includes the extent to which an adolescent has general respect for the police and the law, believes that the law should be obeyed ${ }^{46}$ Baier $\& W r i g h t t^{55}$ address this controversial issue with a meta-analysis of 60 previous studies based on two questions, their findings give confidence that religion does indeed have some deterrent effect of about $r=-.12$ (p. 16).

Social bonding theory provided this study a theoretical platform to analyze whether immigrants' bonds to conventional social institutions such as family, friends, marriage, and work help inhibit him or her from acting on criminal motivations. ${ }^{56}$ Following social bonding theory, this study tested the following questions in Taiwan's immigration context:

i. Hypothesis 1: Among the four elements of the social bond, belief is the best predictor of immigrant crime and delinquency.

ii. Hypothesis 2: Among the four elements of the social bond, attachment is the second best predictor of immigrant crime and delinquency.

iii. Hypothesis 3: Immigrants who have attained higher levels of 
education are less likely to engage in crime and delinquency than those who attained lower levels of education.

iv. Hypothesis 4: Immigrants who attended religious services regularly are less likely to engage in crime and delinquency than those who didn't attend any religious service.

v. Hypothesis 5: Chinese immigrants are less likely to engage in crime and delinquency than other ethnic immigrants.

\section{Data collection and sample}

The data were collected in 2014 and divided into two categories. One was labeled "crime offender" whose data were collected from Taipei prison. The other was coded "non-offender" whose data was collected from five NIA's (National Immigration Agency) service centers and the method of snowball sampling was employed. Criminal offenders were recruited from Taiwan's Taipei prison that housed all foreign inmates countrywide. This study was approved under full board procedures by the SHSU PHSC-IRB on Jan. 17, 2013. The statistics released by Taiwan's Taipei Prison of Ministry of Justice, the only ONE prison containing foreign inmates, indicated that 424 foreigners were held at the end of August, 2012. Among them, 77 were Thais who composed the biggest group, followed by 70 Malaysian and 70 Vietnamese. The survey was conducted between February and May of 2013 and 256 respondents who voluntarily joined this study which reflected the response rate of 60.37 percent. In addition, this study used a control group outside the prison by sampling foreign immigrants the equal number to foreign inmates. Due to the strict regulation by Taiwan's "Personal Identity Information Protection Act," National Immigration Agency's (NIA) officials declined to provide the researcher the complete name list of foreigner's personal and contact information. Without the population framework, this study had no way to do random selection for this comparative group. Instead, this study modified to purposive sampling. The questionnaire was given to those foreign immigrants who walked into or happened to be NIA's service centers in order to seek service or assistance from NIA local office. NIA's service centers were chosen from Taipei city, Taoyuan, Yilan, Hsin-Chu, and Nan-tou counties. Data were collected from 512 foreign immigrants but only 269 were in valid. The response rate was 52.5 percent.

\section{Measurement of variables}

A questionnaire was designed by the researcher as a venue to collect the data. Most questions were designed by closed-ended (structured) approach, but some were open to let respondents fill in. The questionnaire was administered in four languages, including Chinese English, Indonesians; and Vietnamese.

\section{Missing data and extreme values}

The initial data was composed of 256 criminal offenders and 269 non-offenders. The number was 525 in total; meanwhile, not every response had good quality. This study used Listwise deletion to exclude 34 cases in which missing data of variables were more than half of all items. The valid number of usable surveys therefore was reduced to 493 . For those cases with missing data less than 50 percent, this study used the method of Mean Substitution to replace missing values of continuous data and used Mode Substitution to replace missing values of categorical data. This study also applied boxplot to identify extreme values, which are in relation to the rest of the data, and examine each continuous variable.

\section{Demographic background variables}

Respondents identified their ethnicity by selecting one of seven nationality categories: "China," "Indonesia," "Vietnam," "Thailand," "Malaysia," "Philippines," "Others," and clarified themselves with the birth place. A respondent's sex was female $=0$, male $=1$, whereas age was calculated by using respondents' birth year. Educational attainments were proxies for ties to conventional goal which include: "primary (unfinished); primary (finished); some secondary; completed high school; some occupational training; completed undergraduate; and completed postgraduate."

\section{Dependent variables (outcome variables)}

Crime has referred to acts prohibited, prosecuted, and punished by criminal law. The criterion of "court conviction" was the guideline to define the "crime" in this study. Delinquency was not measured by official police record, instead it was subject to the honesty of respondents' self-report including the behaviors of public drunkenness, fighting, gambling, stealing, and police contacts which were very similar to those in the United States (for example, see Elliott \& Ageton, 1980).

\section{Independent variables}

This study attempted to focus on the absence of immigrant's constraints that increased the costs and risks of delinquent behavior and crime. These constraints may involve employment, marriage, friends, religion attendance, etc. Those factors are believed to have a constraining effect on delinquent behaviors and crime. The descriptions of independent variables are as follows:

Family background variables: Family size was measured by the number of children living at a respondent's home. Family intactness was measured by its relational as well as structural dimensions: a respondent's perceived marital harmony of his or her parents. This study asked for the respondent's marital status, and whether he/ she has kids. For those foreigners who were married with Taiwan nationals, the marriage was assumed to have stronger ties with Taiwan society; on the contrary, those who were married in their home country but separated from their spouse were assumed to have weaker bonding. The marital status can be multiple answered. Each of these was surrogate measure of control theory concepts of adult-level attachment and commitment to marriage.

Family process variables: Family bonding variables focused on Hirschi's concept of attachment to parents and spouse, which included three key dimensions: affective relations, close communication, and parental/spousal supervision. The attachment may vary over time for the same person. A respondent's affective relations with his or her parents were measured by 3 items ( 1 item for spouse) which included "My parents treat me fairly"; "I get along well with my parents"; "My parents/spouse understands me." Close communication then included the discussion of working condition, the things of interest, and the things have done with parents/spouse. The caring and trust scale included 5 items ( 2 for spouse): "trust me to do what they expect without checking up on me"; care about how well I do"; "like the group of friends associating with"; "checked on a place to stay in Taiwan"; and "checked on working condition." Identity support contained two more negatively worded items: parents/spouse required to save money and limit the money can spend. 
Work process variables: Work bonding variables focused on the commitment and involvement that the respondents had in their daily life both in Taiwan and in their home countries. To comply with Hirschi's theory, this study hypothesized the more time the respondents spent on work, the lesser they spent with friends which could reduce their involvement with criminal activity or delinquent behaviors. Hence, this study was interested to know how strong commitment the respondent had at work, i.e. how many hours the respondent spent on work per week. Five items were designed to test the respondent's attitude toward his/her colleagues and boss. The satisfaction with salary was also seen as an indicator of work commitment.

Peer processes variables: A respondent's attachment to his peers both in home country and in Taiwan was measured by 3 items: discussed the working condition with friends; discussed the things of interest with my friends; and discussed the things have done with friends. Based on the literature review, this survey included six items asking respondent's close friends' attitudes toward work and delinquency. The questions of "how much time spent with friends" and "how many phone calls made to friends in one day" can also verify the extent of involvement with friends.

Cognitive processes (value) variables: To measure Hirschi's concept of belief, this study employed 12 items in the survey that asked each respondent how often he or she feel that it is okay for him or her to commit deviant behaviors, ranging in seriousness from being late for work to breaking Taiwan's laws. The 12 items were combined into an index of conventional attitudes, including drink at work, drunk on off days, skip work without notice, cheat or steal in work, fighting, steal, destroy or damage property, drug using, weapon possessing, sex with any person and break Taiwan's rules and laws.

Religion attendance variables: Four questions were asked to test the possible effects that attending religious services had on strengthening the respondent's personal bonding to Taiwan's new environment. Religion was coded separately as Christianity, Catholicism, Buddhism, Taoism, Muslim, and others. Also, the researcher was interested to know how often the respondent attended religious services in Taiwan. If he/she ever attended religious services, he/she was free to fill in the number of hours per week, or just go sometimes.

In sum, the attachment score covered the variables of attachment to parents, spouse, friends in home country, and friends in Taiwan. Commitment to conventional goals was measured by the average score of work in Taiwan and in home country. Both variables evaluated the same concept, i.e. respondent's attitude toward the work, boss and coworkers. Involvement in conventional activities was assessed by asking the participants "how many hours spend on work each week," "how many hours did you spend with your friends or coworkers per week," and "how many phone calls did you make to your friends within a day." The belief score was composed of religion score and value score.

\section{Correlation test}

Bivariate statistics were employed to address the relationship between the social bonding variables and dependent variables in (Table 1) and (Table 2). Attachment measure is related to both crime $(\mathrm{r}=.200, \mathrm{p}<.001)$ and delinquency $(\mathrm{r}=-.105, \mathrm{p}<.05)$. Commitment measure is related to belief $(\mathrm{r}=-.239, \mathrm{p}<.001)$ and crime $(\mathrm{r}=.283$, $\mathrm{p}<.001)$. Involvement is related to belief $(\mathrm{r}=-.140, \mathrm{p}<.001)$ and delinquency $(\mathrm{r}=.262, \mathrm{p}<.001)$. Crime is also related to delinquency $(\mathrm{r}=.183, \mathrm{p}<.001)$. These bivariate relationships were reported significantly at different levels.

\section{Results}

\section{Descriptive analysis}

51.9 percent of respondents were criminal offenders (256 cases), and 48 percent were non-offenders (237 cases). 61.7 percent of respondents were males (304 cases), and female respondents took up 38.3 percent (189 cases) of the sample (Table 1$)$.

Table I Nationality of Criminals and Non-Criminals $(\mathrm{N}=493)$

\begin{tabular}{llllll}
\hline \multicolumn{2}{c}{ Crime } & \multicolumn{3}{c}{ Gender } \\
\hline Nationality & Yes & No & Total & Male & Female \\
\hline China & 11 & 10 & $21(4.3 \%)$ & 11 & 10 \\
Indonesia & 15 & 114 & $129(26.2 \%)$ & 19 & 110 \\
Vietnam & 43 & 94 & $137(27.8 \%)$ & 86 & 51 \\
Thailand & 61 & 3 & $64(13 \%)$ & 61 & 3 \\
Malaysia & 51 & 1 & $52(10.5 \%)$ & 51 & 1 \\
Philippines & 8 & 13 & $21(4.3 \%)$ & 8 & 13 \\
Others & 67 & 2 & $69(13.99 \%)$ & 68 & 1 \\
Total & 256 & 237 & $493(100 \%)$ & 304 & 189 \\
& $(51.9 \%)$ & $(48.1 \%)$ & & & \\
\end{tabular}

Note. Respondents in Taipei prison are all males which mean all 256 offenders are all males. In the sample of non-offenders, it composes 189 females and 48 males.

All criminal offenders are males, which can be explained by Taiwan prison's disproportional sex distribution. Therefore, 304 are males and 189 are females among all cases. Among 493 cases, 137 with Vietnamese nationality occupy first place (27.8 percent), followed by 129 Indonesians ( 26.2 percent), 64 Thais (13 percent), 52 Malaysians (10.5 percent), 21 Filipinos ( 4.3 percent) and 69 from other countries. The above sample proportion fairly reflects the actual number of each country's residence in Taiwan, with the exception of the fact that there were only 21 Chinese ( 4.3 percent) included in this study. This phenomenon could be explained in two ways. First, Taiwan government allowed tourism from People Republic of China's citizens in January 2002 and China's economy grew at the highest growth rate in the world, an average rate of 10 percent annual during the period of 1990-2004. The number of Chinese immigrants, legal or illegal, who have stayed in Taiwan has decreased since 2003.

On December 15, 2008, representatives of Taiwan and Mainland China governments signed an agreement to resume direct links of sea, air, and postal services. This movement terminated an almost six-decade-long ban on such trips. In the past, flights from the two regions required a connection at Hong Kong, and doubled the travel times. Second, Taiwan's current government, President Ma YingJeou in particular, is friendly toward China. The resulting pro-China policy has led to speeding up deportations, thus shortening the time of deporting Chinese criminal offenders and immigration law violators. 201 respondents stayed in Taiwan more than five years. 122 respondents stayed in Taiwan between three and five years, and 119 respondents stayed in Taiwan between 1 and 2 years. Only 
51 respondents stayed less than one year in Taiwan. With regard to respondents' marital status, 188 respondents are single (38.1 percent). 170 respondents are married in their home countries ( 34.5 percent). A total of 40 respondents indicated that they have steady relationships, i.e. boyfriends or girlfriends, in their home countries or in Taiwan. Only 16 respondents ( 3.2 percent) are married to a Taiwanese. 260 respondents gave positive answer to the question of "do you have children?" 233 respondents claimed having "no" kids. The percentage of having kids is slightly larger than no kids which is 52.7 percent v. s. 47.3 percent. In the variable of education, there are seven items covering from primary level to postgraduate. The highest frequency falls on "completed high school" with 194 respondents (39.4 percent).

This was followed by "some secondary," 155 respondents $(31.4$ percent), and "finished primary" ranked in third place with 48 respondents ( 9.7 percent). The least number is as expected as fell in "completed postgraduate." Only 6 out of 493 (1.2 percent) completed a graduate program. The average time that offenders were arrested after entering Taiwan was 1.35 years. However, the maximum was 31 years which is in sharp contrast of those offenders who were arrested at the airport. The average age of 493 respondents was 33 years. The oldest respondent was 64 years and the youngest one was 19 years. About half of respondents had one child and 5 were maximum (Table 2).

Table 2 Demographic Characteristics $(\mathrm{N}=493)$

\begin{tabular}{|c|c|c|c|c|}
\hline Variables & Min. & Max. & Mean & $\begin{array}{l}\text { Standard } \\
\text { deviation }\end{array}$ \\
\hline Age & 19 & 64 & 33.93 & 8.462 \\
\hline Children & 0 & 5 & 0.98 & 1.159 \\
\hline Job in Taiwan & 0 & 20 & 2.1 & 2.099 \\
\hline $\begin{array}{l}\text { Work hours in Taiwan/ } \\
\text { week }\end{array}$ & 0 & 140 & 40.08 & 34.085 \\
\hline Job in home country & 0 & 16 & 2.83 & 2.013 \\
\hline $\begin{array}{l}\text { Work hours in home } \\
\text { country/week }\end{array}$ & 0 & 108 & 41.49 & 21.869 \\
\hline $\begin{array}{l}\text { Hours spent with } \\
\text { friends in home country/ } \\
\text { week }\end{array}$ & 0 & 75 & 12.4 & 12.314 \\
\hline $\begin{array}{l}\text { Calls to friends in home } \\
\text { country/ day }\end{array}$ & 0 & 30 & 4.69 & 4.153 \\
\hline Friend number in Taiwan & 0 & 50 & 4.73 & 5.663 \\
\hline $\begin{array}{l}\text { Hours spent with } \\
\text { Taiwan's friends/week }\end{array}$ & 0 & 56 & 6.51 & 8.167 \\
\hline $\begin{array}{l}\text { Calls to friends in } \\
\text { Taiwan/day }\end{array}$ & 0 & 30 & 3.23 & 3.845 \\
\hline $\begin{array}{l}\text { Religious attendance } \\
\text { time(s)/week }\end{array}$ & 0 & 35 & 2.29 & 3.903 \\
\hline $\begin{array}{l}\text { Public drunk in Taiwan/ } \\
\text { times }\end{array}$ & 0 & 50 & 0.64 & 2.901 \\
\hline Fighting in Taiwan/times & 0 & 50 & 0.45 & 2.637 \\
\hline $\begin{array}{l}\text { Gambling in Taiwan/ } \\
\text { times }\end{array}$ & 0 & 100 & 1.14 & 7.341 \\
\hline Stealing in Taiwan/times & 0 & 6 & 0.14 & 0.695 \\
\hline Police contact times & 0 & 20 & 0.48 & $\mathrm{I} .347$ \\
\hline
\end{tabular}

\begin{tabular}{lllll}
\hline Variables & Min. & Max. & Mean & $\begin{array}{l}\text { Standard } \\
\text { deviation }\end{array}$ \\
\hline Times entered Taiwan & 1 & 30 & 1.99 & 2.713 \\
\hline
\end{tabular}

\section{Reliability test}

In this study, after applying Cronbach's alpha test to 7constructs which contained 63 Likert-Scale items, score was between 0.661 and 0.923. The highest is belonged to the construct of "Spouse" which meant the items in the "Spouse" had highest internal consistency. The lowest was attributed to the construct of "Friends in Taiwan." of total 63 items was 0.877 which meant the modal intercorrelation among test items measured several related constructs (Table 3 ).

Table 3 Reliability Test for Independent Variables

\begin{tabular}{lll}
\hline Variables & Number of items & Cronbach's alpha \\
\hline Total & 63 & 0.877 \\
Parents & 12 & 0.887 \\
Spouse & 8 & 0.923 \\
Work in Taiwan & 7 & 0.878 \\
Work in Home Country & 7 & 0.884 \\
Friends in Home Country & 9 & 0.713 \\
Friends in Taiwan & 9 & $0.66 \mathrm{I}$ \\
Cognitive Processes/ & $1 \mathrm{I}$ & 0.872 \\
Values &
\end{tabular}

\section{Validity test / factor analysis}

This study used SPSS 21.0 to conduct factor analysis in seeking to validate its constructs. Before conducting factor analysis, this study used KMO and Bartlett's test to ensure the data are suitable for it. KMO is a measure of sampling adequacy that is recommended to check the case to variable ratio for the analysis being conducted. While the KMO ranges from 0 to 1 , the conventionally accepted score is over 0.6. Also, the Bartlett's Test of Sphericity relates to the significance of the study and shows the validity and suitability of the responses collected to the problem being addressed through the study. For Factor Analysis to be done, the Bartlett's Test of Sphericity must be less than 0.05 . In this study, the KMO is 0.876 and the Bartlett's test is significant (less than 0.05), which means the data set is suitable for factor analysis.

Another important aspect that needs mentioned is Principal Component Analysis (PCA) and Rotated Component Matrix. In this study, seven components were developed. The first principal component is scored 14.255 and accounts for 14.255 percent variance, and followed by 12.794 (second component), 8.287 (third component), 5.985 (fourth component), 4.844 (fifth component), 4.015 (sixth component), and 3.571 (seventh component). The total variance explained is 53.751 percent for the above seven components and explain at least fifty percent of variance. When deciding how many factors to analyze is determining whether a variable relates to more than one factor. Rotation maximizes high item loadings and minimizes low item loadings, thereby producing a more interpretable and simplified solution. The primary objectives are to provide easier interpretation of results and produce a solution that is more parsimonious. In this study, the principal components are "Parents," "Value," "Spouse," "Friend-1," "Work at Home Country," "Work in Taiwan," and "Friend-2" (Table 4). 
Table 4 Total Variance Explained

\begin{tabular}{lllllll}
\hline & \multicolumn{3}{l}{ Initial eigenvalues } & & \multicolumn{3}{l}{ Rotation Sums of squared loadings } \\
\hline Component & Total & \% of Variance & Cumulative \% & Total & $\%$ of Variance & Cumulative \% \\
\hline 1 & 8.981 & 14.255 & 14.255 & 5.605 & 8.896 & 8.896 \\
2 & 8.06 & 12.794 & 27.049 & 5.581 & 8.858 & 17.754 \\
3 & 5.221 & 8.287 & 35.336 & 5.504 & 8.736 & 26.49 \\
4 & 3.771 & 5.985 & 41.321 & 4.742 & 7.527 & 34.018 \\
5 & 3.052 & 4.844 & 46.165 & 4.688 & 7.442 & 41.459 \\
6 & 2.529 & 4.015 & 50.18 & 4.179 & 6.633 & 48.093 \\
7 & 2.25 & 3.571 & 53.751 & 3.565 & 5.659 & 53.751 \\
\hline
\end{tabular}

\section{Crime prediction}

This model used 5 demographic variables (age, gender, education, marriage, children), 4 construct variables (attachment, commitment, involvement, belief) and five other variables (work full time, Chinesespeaking, friends in Taiwan, religion attendance, and legally entered Taiwan) to predict immigrant crime. Logistic regression is used to predict crime of foreigners in Taiwan. Crime is the dependent variable (coded 1 if immigrant was a criminal offender and coded 0 if immigrant was a non-offender) and the four construct variables attachment, commitment, involvement, and belief as independent variables. Omnibus tests are used to explore significant differences between blocks of independent explanatory variables and their coefficients. They test whether the explained variance in a set of data is significantly greater than the unexplained variance. The model Chi-square, 543.924 and P-value is $0.000(\mathrm{p}<0.05)$, which means the independent variables make better prediction for the dependent variable. To determine which independent variables are important, we examine each independent variable. The Wald statistics suggested that 5 variables have significant effects on the dependent variable. The logistic regression coefficient (B) for age is 0.16 which means older immigrants are more likely to commit crime. The $\operatorname{Exp}(\beta)$ of age is 1.17 , implying that the odds change when age increases by one unit. The logistic regression coefficient (B) for "Chinese speaking" is 2.935 which means Chinse-speaking immigrants are more likely to commit crime. The logistic regression coefficient (B) for religion attendance is 2.519 which means immigrants who attended more religion activity are more likely to commit crime. The $\operatorname{Exp}(\beta)$ of age is 12.4 , implying that the odds change when religion attendance increases by one unit.

The other two variables ("work full time" and "belief") have negative Beta, which means immigrants who work full time and have stronger belief are less likely to commit crime. The $\operatorname{Exp}(\beta)$ of the two variable are less than 1 , which means the odds are decreased (Table 2). This study applied Hosmer-Lemeshow test to test for goodness of fit for logistic regression models. The Hosmer-Lemeshow test is widely used to answer the question "How well does my model fit the data?" The goodness-of-fit tests help the researcher decide whether this model is correctly specified. According to the Test, the p-value is 0.969 which is much higher than $.05(\mathrm{p}>0.05)$, suggesting the model fits the data (Table 5). From this fitted model, the accuracy of the classification is measured by its sensitivity (the ability to predict a crime correctly) and specificity (the ability to predict a non-crime correctly). In this study, the sensitivity is 96.1 percent and the specificity is 91.6 percent. Since the immigrant criminal offenders were 256 among 493 cases (51.9 percent) in the sample, the cut value is therefore set at 0.5 (50 percent). The overall correct percentage of prediction is 93.9 percent (Table 2). The predictive efficiency is lambda-p $(\lambda p)$ which is calculated by the number of cases in the smaller observed category minus the number of cases incorrectly predicted by the model, divided by the number of cases in the smaller observed category. In this model, $\lambda \mathrm{p}=237-(10+20) / 237=0.8734$ (Table 6).

Table 5 Test Results of All Variables, Crime Model $7(\mathrm{~N}=493)$

\begin{tabular}{|c|c|c|c|c|c|c|c|c|c|c|}
\hline Variables & Min. & Max. & Mean & S.D. & B & Wald & Chi-square & df & Sig. & $\operatorname{Exp}(B)$ \\
\hline Children & 0 & 5 & 0.98 & 1.15 & -0.084 & 0.063 & & 1 & 0.802 & 0.919 \\
\hline Age & 19 & 64 & 33.93 & 8.64 & 0.16 & 9.042 & & I & 0.003 & 1.17 \\
\hline Education & 1 & 7 & 3.47 & 1.21 & -0.036 & 0.029 & & I & 0.864 & 0.965 \\
\hline Marriage & 0 & I & 0.52 & 0.5 & 0.302 & 0.21 & & I & 0.647 & 1.35 \\
\hline Gender & 0 & I & 0.52 & 0.5 & -24.03 & 0 & & I & 0.992 & 0 \\
\hline Work full time & 0 & I & 0.47 & 0.5 & -1.239 & 7.24 & & I & 0.007 & 0.29 \\
\hline Chinese Speaking & 0 & I & 0.29 & 0.455 & 2.935 & 7.522 & & I & 0.006 & 18.8 \\
\hline Friends in Taiwan & 0 & 50 & 4.73 & 5.66 & -0.006 & 0.055 & & I & 0.814 & 0.994 \\
\hline Religion Attendance & -1.5 & 2.68 & 0 & 0.586 & 2.519 & 10.69 & & I & 0.001 & 12.4 \\
\hline Legally Entered Taiwan & 0 & I & 0.1136 & 0.317 & -0.651 & 0.539 & & I & 0.463 & 0.522 \\
\hline Attachment & -6.2 & 4.73 & 0 & 1.77 & -0.153 & 0.907 & & I & 0.341 & 0.858 \\
\hline Commitment & -3.76 & 3.19 & 0 & 1.31 & -0.186 & $0.85 I$ & & I & 0.356 & 0.83 \\
\hline
\end{tabular}


Table Continued

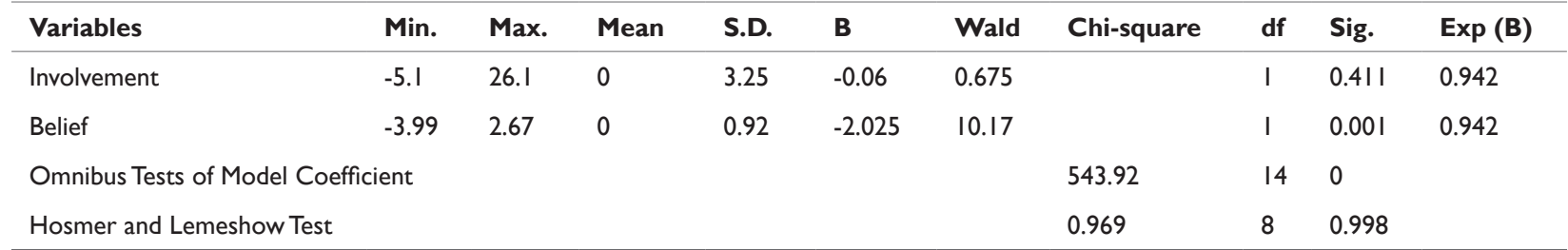

Note.Variable(s) entered on step I: Children,Age, Gender, Marriage, Education, Chinese Speaking, Work Full Time, Legally Entered Taiwan, Friends in Taiwan, Religion Attendance, Attachment, Belief, Commitment, Involvement. Pseudo R2: Cox\& Snell R = .668; Nagelkerke R = .89I.

Table 6 Classification Table of Crime Model 7

\begin{tabular}{lllll}
\hline \multirow{2}{*}{ Observed } & \multicolumn{3}{c}{ Predicted } \\
\cline { 2 - 5 } & \multicolumn{3}{c}{ Crime } & Percentage correct \\
\hline \multirow{3}{*}{ Crime } & No & 217 & 20 & 91.6 \\
& Yes & 10 & 246 & 96.1 \\
& Overall Percentage & & 93.9
\end{tabular}

Note. The cut value is .500

The disadvantage of this classification table is that it doesn't reveal the distribution of estimated probability for each case. Furthermore, we used pseudo R2 (RL2) to test this model. In the logistic regression model, RL2 = GM / (GM + DM). GM or the model Chi-square is 517.412. The value of DM is -2 LL shown in the Model Summary table which is 165.299 . The RL2 is $5127412 / 517.412+165.299=0.7578$ which suggests a strong association between 7 independent variables and crime.

\section{Delinquency prediction}

This model used 5 demographic variables (age, gender, education, marriage, children), 4 construct variables (attachment, commitment, involvement, belief) and five above other variables (work full time, Chinese-speaking, friends in Taiwan, religion attendance, and legally entered Taiwan) to predict immigrant delinquency. As the multiple regression equation has been constructed, we checked how good it is by examining the coefficient of determination (R2). R2 always lies between 0 and 1 . The closer $\mathrm{R} 2$ is to 1 , the better is the model and its prediction. In this model, R2 is 0.147 which means only 14.7 percent of the variation in the badhehavior Zscore can be explained by four construct variables (Table 7). The coefficients table showed that the variable of involvement, belief, and Chinese-speaking are statistically significant. Beta of belief is negative which means immigrants who have strong beliefs are less likely to engage in delinquent behaviors. Beta of Chinese-speaking variable is also negative which means Chinese-speaking immigrants are less likely to be involved in delinquent behavior. Beta of involvement is positive, suggesting immigrants who spend time in work and hang out with friends are more likely to have delinquent behaviors (Table 8).

Table 7 Summary of Delinquency Model 5: Predicted by All Independent and Demographic Variables

\begin{tabular}{|c|c|c|c|c|c|c|c|c|c|}
\hline \multirow{2}{*}{ Model } & \multirow{2}{*}{$\mathbf{R}$} & \multirow{2}{*}{ R Square } & \multirow{2}{*}{ Adjusted R square } & \multirow{2}{*}{ S. E. of the estimate } & \multicolumn{5}{|l|}{ Change statistics } \\
\hline & & & & & R Square change & F Change & dfI & df2 & Sig. F change \\
\hline 1 & 0.383 & 0.147 & 0.122 & 2.49821 & 0.147 & 5.885 & 14 & 478 & 0 \\
\hline
\end{tabular}

Note. Dependent variable: badbehavior Zscore; Predictors: (Constant), Religion Attendance, Education, Gender, Involvement, Legally Entered Taiwan, Friend in Taiwan, Marriage, Attachment, Work Full Time, Commitment, Age, Chinese Speaking, Children, Belief.

Table 8 Coefficients Table of Delinquency Model: Predicted by All Independent and Demographic Variables

\begin{tabular}{|c|c|c|c|c|c|c|c|}
\hline \multirow[t]{2}{*}{ Model } & \multicolumn{2}{|c|}{ Unstandardized coefficients } & \multirow{2}{*}{$\begin{array}{l}\text { Standardized coefficients } \\
\text { Beta }\end{array}$} & \multirow[t]{2}{*}{$\mathbf{t}$} & \multirow[t]{2}{*}{ Sig. } & \multicolumn{2}{|c|}{ Collinearity statistics } \\
\hline & B & S. E. & & & & Tolerance & VIF \\
\hline Children & 0.038 & 0.13 & 0.017 & 0.297 & 0.767 & 0.563 & 1.77 \\
\hline Marriage & -0.539 & 0.284 & -0.101 & -1.9 & 0.058 & 0.631 & 1.58 \\
\hline Age & -0.001 & 0.017 & -0.004 & -0.081 & 0.935 & 0.608 & 1.64 \\
\hline Gender & -0.487 & 0.292 & -0.089 & -1.66 & 0.096 & 0.628 & 1.59 \\
\hline Education & -0.021 & 0.1 & -0.01 & -0.215 & 0.83 & 0.855 & 1.16 \\
\hline Friend in Taiwan & 0.017 & 0.021 & 0.035 & 0.794 & 0.428 & 0.912 & 1.09 \\
\hline Religion Attendance & 0.49 & 0.268 & 0.108 & 1.824 & 0.069 & 0.511 & 1.95 \\
\hline Legally enter Taiwan & -0.36 & 0.365 & -0.043 & -0.986 & 0.325 & 0.943 & 1.06 \\
\hline Work Full Time & -0.172 & 0.255 & -0.032 & -0.672 & 0.502 & 0.779 & 1.28 \\
\hline Chinese Speaking & -0.66 & 0.333 & -0.113 & -1.98 & 0.048 & 0.551 & 1.81 \\
\hline Attachment & -0.072 & 0.07 & -0.048 & -1.02 & 0.308 & 0.812 & 1.23 \\
\hline Commitment & 0.029 & 0.103 & 0.014 & 0.284 & 0.777 & 0.694 & 1.44 \\
\hline
\end{tabular}


Table Continued

\begin{tabular}{llllllll}
\hline Model & \multicolumn{2}{l}{ Unstandardized coefficients } & Standardized coefficients & t & & Sig. & \multicolumn{2}{c}{ Collinearity statistics } \\
\hline & B & S. E. & Beta & & & Tolerance & VIF \\
\hline Involvement & 0.185 & 0.038 & 0.226 & 4.855 & 0 & 0.825 & 1.21 \\
Belief & -0.777 & 0.185 & -0.269 & -4.21 & 0 & 0.438 & 2.28 \\
\hline
\end{tabular}

Note. Dependent variable: badbehavior_Zscore; Predictors: (Constant), Religion Attendance, Education, Gender, Involvement, Legally Entered Taiwan, Friend in Taiwan, Marriage, Attachment, Work Full Time, Commitment, Age, Chinese Speaking, Children, Belief.

Findings

i. Hypothesis 1: Among the four elements of the social bond, belief is the best predictor of immigrant crime and delinquency. Supported.

ii. Hypothesis 2: Among the four elements of the social bond, attachment is the second best predictor of immigrant crime and delinquency. Partially Supported.

iii. Hypothesis 3: Immigrants who have attained higher levels of education are less likely to engage in crime and delinquency than those who attained lower levels of education. Not Supported.

iv. Hypothesis 4: Immigrants who attended religious services regularly are less likely to engage in crime and delinquency than those who didn't attend any religious service. Not Supported.

v. Hypothesis 5: Chinese immigrants are less likely to engage in crime and delinquency than other ethnic immigrants. Not Supported.

\section{Discussion}

$\operatorname{In}^{1}$ and subsequent writings up to 1980 , Hirschi was clear that variations in offending over the life course were directly related to variations in the strength of the social bond (as cited in Na \& Paternoster, 2012, p. 429). Consistent with this theoretical development, the researcher was interested in exploring the relationship between social bonds and immigrant crime in Taiwan. To be more specific, this study examined the variations of immigrants' social bonds which were established in their early life in home countries, and changed over time when they moved to Taiwan. Hirschi ${ }^{1}$ also suggested that there should be relationships among the elements of the social bond. The strongest linkages in this study were the variables that measured belief, especially ones related to religion and values. With respect to religion, this study concentrated on the relationship between the indicators of religiousness such as belonging to a religion, attendance times, similar to the measurements used by Baier \& Wright ${ }^{55}$. Although Hirschi and Stark asserted church attendance is unrelated to children's delinquency $(1969$, p. 202), this study found immigrants who attended more religious activities are more likely to commit crime. This finding is sharp contrast to previous studies that religious beliefs exert a moderating effect on individuals' criminal behavior. The finding also does not support Burkett \& White $^{54}$ study that the positive relation between religious participation and crime is only found in "victimless" offenses that secular agencies do not condemn. Instead, most immigrant crime in this study had obvious victims and also were against Taiwan's laws and government. Nevertheless, belief could strongly predict immigrant's crime and delinquency. The value variables measured by the moral element play a crucial role. In other words, an immigrant who identifies himself or herself as a conventional person, that is, as one who cares about what others think about him or her, and who has properly internalized the expectations of significant others, is less likely to deviate. Such immigrants are also more likely to consider the long-term consequences of their actions and indeed, respect for significant others and respect for law, thus engage in conforming behaviors after they transited from home country to host country. The inverse relationship between belief and immigrant crime can help explain the strength of "indirect control," by which immigrants adhered to basic moral values and accepted Taiwan's conventional authority. ${ }^{57-61}$

It is unexpected that the weakest links in the models were variables related to attachment. In the current study, attachment focused on primary groups of immigrants' families and peers. Attachment to parents and spouse, however, was not found significant in the analysis. This finding is different from most literature in social bonding theory and age-graded theory. The immigration context could be a unique factor that underscores the strengths of these two traditional attachments. With regard to the gender effect to the immigrant crime rate, given there is no female foreign inmates participated in the survey, an ANOVA analysis between two gender groups cannot be conducted. Meanwhile, the results consistently implied males are more likely to engage in delinquent behaviors than females. The results may be partially support the argument that adult social bonds affect male and female crime differently. The related study of deviant association and lifestyle would help clarify gendered patterns to immigrant crime. This study also found older immigrants are more likely to commit crime. This finding could be related to their unstable job condition and broken marriage, which cause older immigrants are more likely to engage in crime. Both age and gender are tested positive to affect crime and delinquency in this study.

In sum, there were several propositions tested in these models that may add to existing scholarship. First, the models were first applied to Taiwan and in immigration settings. This study, using Taiwan's sample, empirically studied social bonding theory and tested its validity across different culture and country. Secondly, these models specified belief is positively related to immigrant's crime and delinquent rates in Taiwan. The age and gender have significant effects on predicting immigrant crime and delinquency. Third, immigrants who work full time and hold beliefs are less likely to engage in criminal and delinquent acts. This study used cross-sectional data and collected data from sample of foreign immigrants in Taiwan. This sample might not be representative of all immigrants. The lack of female offenders in the sample limited our ability to reliably measure the difference between male and female criminal offenders. We were unable to test these explanations of findings more directly because of lack of data on the quality of relationships. As illuminated in literature of etiology, the use of longitudinal, panel data would be more desirable in future study.

\section{Acknowledgements}

None.

\section{Conflict of interest}

Author declares that there is no conflict of interest. 


\section{References}

1. Hirschi, T. Causes of Delinquency. University of California Press Berkeley; 1969.

2. Tanton, J, Lutton W. Immigration and criminality in the U.S.A. Journal of Social, Political and Economic Studies, 1993;18;217-234.

3. Mears DP. The immigration-crime Nexus: Toward an analytic framework for assessing and guiding theory, research and policy. Sociological Perspectives. 2001;44(1);1-19.

4. Butcher KF, Piehl AM. Cross-city evidence on the relationship between immigration and crime. Journal of Policy Analysis and Management. $1998 ; 17(3): 457-493$.

5. Sung JJ. Ethnicity and deviance: A study of Asian and non-Asian adolescents in America. Sociological Forum. 2002;17(4):647-680.

6. Sturgeon TJ, Kawakami M. Global value chains in the electronics industry: Was the crisis a window of opportunity for developing countries? 2010

7. Selya RM. Illegal migration in Taiwan: A preliminary overview. Int Migr Rev. 1992;26(3):787-805.

8. Tsai HC, Tsay CL. Foreign workers in Taiwan: Demographic characteristics, related problems, and policy implications. Industry of Free China. 1991;76(3):53-69.

9. Lohrman R. Irregular migration: A rising issue in developing countries. International Migration. 1987;25(3):253-266.

10. Chen QJ. The Study of Crime and Regulations of Foreign Worker in Taiwan (Unpublished Master thesis). National Cheng Kung University: Taiwan: 2005.

11. Lee, C. The tragedy of illegal immigration. In Archive of "About Taiwan/ Public Security," Taiwan Panorama. 2003.

12. Stahl CW. International Labor Migration: A Study of ASEAN Countries. CMS Occasional Papers and Documentation: Staten Island: 1987.

13. Mumford S. Illegal migration, national security, and the church. The Humanist, 1981;41(6):24-30.

14. ROC Taiwan National Immigration Agency. Statistics of Population in Taiwan 1992-2011.2008

15. ROC Taiwan National Immigration Agency. Statistics of Foreign Residence Certificate, divided by City/Province. 2008

16. ROC Taiwan National Immigration Agency. Statistics of Foreign Population, divide by Occupation, Gender and Sending Countries. 2008.

17. ROC Taiwan National Immigration Agency. (2008). Statistics of Visitor and Immigrants from Mainland China, Hong Kong, and Macao. 2008.

18. ROC Taiwan National Immigration Agency. Statistics of Foreign Spouse from Mainland China, Hong, and Macao. 2008.

19. ROC Taiwan National Immigration Agency. Detention and Deportation Statistics of Mainland Chinese in Taiwan. 2008

20. ROC Taiwan National Immigration Agency. Run-away and Deportation Statistics of Foreign Workers. 2008

21. ROC Taiwan Ministry of Justice. Statistics of Foreigners' Crimes and Offenses in Taiwan, 2004-2008. 2009

22. ROC Taiwan Government Information Office.The Story of TaiwanEconomy. 2010.
23. Martínez R, Lee MT. On immigration and crime. In La Free G, Bursik R, editors. Criminal Justice 2000: The Changing Nature of Crime. National Institute of Justice: Washington DC; 2000.

24. Thomas WI, Znaniecki F. The Polish peasant in Europe and America: Volume IV. Gorham Press: Boston; 1920

25. Shaw CR, McKay HD. Juvenile Delinquency and Urban Areas. University of Chicago Press: Chicago; 1942.

26. Hagan J, Palloni A. Immigration and crime in the United States. In Smith JP, Edmonston B, editors. The Immigration Debate: Studies on the Economic, Demographic, and Fiscal Effects of Immigration, National Academies Press: Washington, DC; 1998. p. 367-387.

27. Whyte WF. Street Corner Society: The Social Structure of an Italian Slum. University of Chicago Press: Chicago; 1955.

28. Mears DP. Immigration and crime: What's the Connection? In immigration offenses and non-citizen offenders (March/April 2002) Federal Sentencing Reporter, 2002;14 (5):284-288.

29. Hagan J, Levi R, Dinovitzer R. The symbolic violence of the crimeimmigration nexus: Migrant mythologies in the Americas. Criminology \& Public Policy. 2008;7(1):95-112.

30. Rumbaut RG. Undocumented immigration and rates of crime and imprisonment: Popular myths and empirical realities. 2008.

31. Tonry M. Ethnicity, crime, and immigration. In Tonry M, editor Ethnicity, Crime, and Immigration: Comparative and Cross-National Perspectives. University of Chicago Press: Chicago; 1997: 1-27p.

32. Batta ID, Mawby RI, Mc Culloch, et al. Crime, social problems, and Asian immigration: The Bradford experience. International Journal of Contemporary Sociology. 1981;18:135-168.

33. Hagan J, Palloni A. Social criminology and the mythology of Hispanic immigration and crime. Social Problems. 1999;46(4):617-632.

34. Waters T. Crime and Immigrant Youth. Sage: Thousand Oaks; 1999.

35. Cretacci MA, Rivera CJ, Ding F. Self-control and Chinese deviance: A look behind the bamboo curtain. International Journal of Criminal Justice Sciences. 2009;4(2):131-143.

36. Cretacci MA, Ding F, Rivera CJ. Traditional and bond measures of self-control and their impact on deviance among Chinese university students. International Journal of Criminal Justice Sciences. 2010;5(1):220-238

37. Lu YF, Yu YC, Ren L, et al. Exploring the utility of self-control theory for risky behavior and minor delinquency among Chinese adolescents. Journal of Contemporary Criminal Justice. 2012;29(1):32-52.

38. Cheung NWT, Cheung YW. Self-control, social factors, and delinquency: A test of the general theory of crime among adolescents in Hong Kong. Journal of Youth Adolescence, 2008;37:412-430.

39. Chui WH, Chan HCO. An empirical investigation of social bonds and juvenile delinquency in Hong Kong. Child Youth Care Forum. 2012;41(4):371-386

40. Hwang S, Akers RL. Parental and peer influences on adolescent drug use in Korea. Asian Criminology. 2006;1(1):51-69.

41. Grasmick HG, Tittle CR, Bursick RJ, et al. Testing the core implications of Gottfredson and Hirschi's general theory of crime. Journal of Research in Crime and Delinquency. 1993;30(1):5-29.

42. Hirschi T. Self-control and crime. In Baumeister RF, Vohs KD, editors. Handbook of Self-Regulation: Research, Theory, and Applications. The Guilford press: New York; 2004. p. 537-552. 
43. Cretacci MA. Religion and social control: an application of a modified social bond on violence. Criminal Justice Review. 2003;28(2):254-277.

44. Bouffard JA, Rice SK. The influence of the social bond on self-control at the moment decision: Testing Hirschi's redefinition of self-control. American Journal of Criminal Justice. 2011;36(2):138-157.

45. Hirschi T, Stark, R. Hellfire and Delinquency. Social Problems. 1969;17(2):202-213.

46. Akers RL. Criminological Theories: Introduction, Evaluation, and Application. $3^{\text {rd }}$ edn. CA: Roxbury; 2000.

47. Agnew R. A longitudinal test of social control theory and delinquency Journal of Research in Crime and Delinquency. 1991;28(2):126-156.

48. Booth JA, Farrell A, Varano SP. Social control, serious delinquency, and risky behavior. Crime \& Delinquency. 2008;54(3):429-456.

49. Schroeder RD, Giordano PC, Cernkovich SA. Adult child-parent bonds and life course criminality. Journal of Criminal Justice. 2010;38(4);562-571.

50. Massey DS. Social structure, household strategies, and the cumulative causation of migration. Popul Index. 1990;56(1):3-26.

51. Tsay CL. Taiwan: Labour importer. ASIAN Economic Bulletin 1995;12(2):175-190.

52. Begg DJ, Langley JD, Moffitt T, et al. Sports and delinquency: An examination of the deterrence hypothesis in a longitudinal study. British Journal of Sports Medicine, 1966;30(4):335-341.

53. Chriss James J. The functions of the social bond. The Sociological Quarterly. 2007;48:689-712.

54. Burkett SR, White M. Hellfire and Delinquency: Another look. Journal for the Scientific Study of Religion, 1974;13(4):455-462.

55. Baier CJ, Wright BRE. "If you love me, keep my commandments": A meta-analysis of the effect of religion on crime. Journal of Research in Crime and Delinquency. 2001;38(1):3-21.

56. Curran DJ, Renzetti CM. Theories of Crime. $2^{\text {nd }}$ edn. Allyn \& Bacon: 2001.

57. Martinez, R. Coming to America: The impact of the new immigration on crime. In Martinez R,Valenzuela A, editors. Coming to America: Immigration Ethnicity, and Crime. University Press: New York; 2006.

58. Rumbaut RG, Ewing WA. The Myth of Immigrant Criminality. 2007.

59. Sellin T. Culture Conflict and Crime. Social Science Research Council: New York; 1938.

60. Sutherland EH. Criminology. JB Lippincott: Philadelphia; 1924.

61. Taipei prison, Agency of Corrections, Ministry of Justice. 